ISSN.2621-9832

JURNAL MathEdu (MathematicEducationJournal) http://journal.ipts.ac.id/index.php/MathEdu Vol. 4 . No. 3 November 2021

\title{
PENGARUH MOTIVASI DAN MINAT TERHADAP HASIL BELAJAR MATEMATIKA PADA POKOK BAHASAN PERSAMAAN LINEAR SATU VARIABEL PADA SISWA KELAS VII SMP NEGERI 9 PADANGSIDIMPUAN
}

\author{
Oleh: \\ Yanti Novita Sitompul, Mohd. Arifin , Nurdalilah
}

\begin{abstract}
ABSTRAK
Pengaruh Motivasi dan Minat Terhadap Hasil Belajar Matematika Pada Pokok Bahasan Persamaan Liniear Satu Variabel Pada siswa kelas VII SMP Negeri 9 Padangsidimpuan. Salah satu yang harus ditumbuhkembangkan dalam pembelajaran matematika adalah motivasi dan minat belajar siswa, karena motivasi dan minat belajar mempunyai peranan yang penting dalam menentukan keberhasilan siswa. Penelitian ini ditujukan untuk mengetahui adakah pengaruh motivasi dan minat belajar siswa terhadap hasil belajar pada pokok bahasan persamaan liniear satu variabel. Populasi dalam penelitian ini adalah adalah siswa kelas VII SMP Negeri 9 Padangsidimpuan, dengan jumlah kelas VII sebanyak 8 kelas. Pada penelitian ini sampel diambil dari populasi dengan teknik Cluster Random Sampling yaitu penelitin mengambil sampelnya berdasarkan daerah populasi yang telah ditetapkan. Jumlah sampel adalah 32 siswa. Metode pengumpulan data yang digunakan pada penelitian ini adalah metode kuisioner dan dokumentasi. Untuk analisis data akhir menggunakan Regresi Linier ganda. Hasil Penelitian diperoleh persamaan estimasi regresi linier ganda untuk semua siswaadalah $\hat{Y}=39+0,79 X_{1}+1,02 X_{2}$ dengan koefisien korelasi parsial $r_{y 12}$ sebesar 0,490, menunjukkan adanya hubungan antara motivasi siswa terhadap hasil belajar matematika. Nilai koefisien korelasi positif menunjukkan bahwa hubungan antara motivasi dan hasil belajar searah. Koefisien korelasi parsial $r_{y 21}$ sebesar 0,293, ini menunjukkan adanya hubungan antara minat siswa terhadap hasil belajar matematika. Nilai koefisien korelasi positif menunjukkan bahwa hubungan antara minat dan hasil belajar searah. Setelah koefisien korelasi parsial diuji keberartiannya, ternyata kedua koefisien berarti, artinya hubungan antara motivasi siswa dengan hasil belajar matematika jika minat tetap adalah signifikan. Kata Kunci: Motivasi, Minat dan Hasil Belajar
\end{abstract}

\begin{abstract}
ABSTRAK
One thing that must be developed in learning mathematics is students' motivation and interest in learning, because motivation and interest in learning have an important role in determining student success. This study aimed to determine whether there is an effect of student motivation and interest in learning on learning outcomes on the subject of linear equations of one variable. The population in this study were seventh grade students of SMP Negeri 9 Padangsidimpuan, with a total of 8 classes of VII class. In this study, the sample was taken from the population using the Cluster Random Sampling technique, namely the research took the sample based on a predetermined population area. The number of samples is 32 students. The data collection method used in this study is a questionnaire and documentation method. For the final data analysis using multiple Linear Regression. The results of the study obtained that the estimation equation for multiple linear regression for all students was $=39+0.79+1.02$ with a partial correlation coefficient of 0.490, indicating a relationship between student motivation and learning outcomes in mathematics. The positive correlation coefficient value indicates that the relationship between motivation and learning outcomes is unidirectional. Partial correlation coefficient of 0.293 , this indicates a relationship between student interest in mathematics learning outcomes. The positive correlation coefficient value indicates that the relationship between interest and learning outcomes is unidirectional. After the partial correlation coefficient was tested for significance, it turned out that both coefficients were significant, meaning that the relationship between student motivation and learning outcomes in mathematics if interest remained significant.
\end{abstract}

Keywords: Motivation, Interest and Learning Outcomes

\section{PENDAHULUAN}

Penyelenggara pendidikan disekolah dilakukan melalui proses belajar mengajar. Didalam pelaksanaannya tidak selalu berjalan dengan baik, karena sering terdapat beberapa hambatan. Namun hambatan itu masih bisa diatasi apabila dalam proses belajar mengajar dilakukan dengan disiplin. Keberhasilan siswa dalam mempelajari materi pelajaran dinyatakan dengan hasil belajar. Hasil belajar siswa tersebut merupakan gambaran keberhasilan siswa dalam proses belajar. Tinggi rendahnya hasil belajar siswa merupakan alat untuk mengetahui seorang siswa mengalami perubahan atau tidak dalam belajar. 
ISSN.2621-9832

JURNAL MathEdu (MathematicEducationJournal) http://journal.ipts.ac.id/index.php/MathEdu

Vol. 4 . No. 3 November 2021

Berdasarkan wawancara dengan beberapa guru mata pelajaran matematika di SMP, hasil belajar siswa pada materi pelajaran persamaan linear satu variabel banyak yang mendapat nilai rendah. Salah satu faktor penyebabnya adalah motivasi dan minat. Slameto juga menyatakan sekurang - kurangnya ada tujuh faktor yang tergolong kedalam faktor yang mempengaruhi hasil belajar. Faktor - faktor itu adalah : intelegensi, perhatian, minat, bakat, motivasi, kematangan dan kelelahan (Slameto 2003:55).

Motivasi belajar sangat penting bagi siswa dan guru. Bagi siswa pentingnya motivasi adalah sebagai berikut : (1) menyadarkan kedudukan pada awal belajar, proses, dan hasil akhir, (2) mengimformasikan tentang kekuatan usaha belajar, yang dibanding dengan teman sebaya, (3) mengarahkan kegiatan belajar, (4) membesarkan semangat belajar, dan (5) menyadarkan tentang adanya perjalanan belajar dan kemudian bekerja (disela - sela jam istrahat dan bermain) yang berkesinambungan (Dimyati 200:85). Kelima hal tersebut menunjukkan berapa pentingnya motivasi tersebut disadari oleh pelakunya sendiri. Bila motivasi disadari oleh pelaku, maka suatu pekerjaaan, dalam hal tugas belajar akan diselesaikan dengan baik.

Minat diartikan sebagai suatu kondisi yang terjadi apabila seseorang melihat ciri-ciri atau arti sementara situasi yang dihubungkan dengan keinginan-keinginan atau kebutuhan-kebutuhannya sendiri. Oleh karena itu, apa yang dilihat seseorang akan tentu akan membangkitkan minatnya sejauh apa yang dilihatnya itu mempunyai hubungan dengan kepentingannya sendiri. Hal ini menunjukkan bahwa minat merupakan kecenderungan dalam jiwa seseorang kepada seseorang (biasanya disertai dengan perasaan senang), karena itu merasa ada kepentingan dengan sesuatu itu. Bernard (dalam Sardiman 2007: 76) minat timbul tidak secara tiba - tiba atau spontan, melainkan timbul akibat dari partisipasi, pengalaman, kebiasaan pada waktu belajar dan bekerja. Jadi jelas bahwa soal minat akan selalu berkait dengan soal kebutuhan atau keinginan. Oleh karena itu yang penting bagaimana menciptakan kondisi tertentu agar siswa selalu butuh dan ingin terus belajar.

Tugas pertama guru adalah mengenal dan memahami siswa dalam proses belajar mengajar sehingga kemampuan guru dalam berinteraksi dengan siswa tidak hanya dipakai untuk mentransfer ilmu saja tetapi guru dapat mempelajari siswa, mengawasi tingkah laku dan kegiatannya (Atminingsih, 2006). Berdasarkan uraian dari latar belakang tersebut penulis tertarik untuk melakukan penelitian dengan mengangkat judul "pengaruh motivasi dan minat terhadap hasil belajar matematika pada pokok bahasan persamaan linear satu variabel pada siswa kelas vii smp negeri 9 padangsidimpuan”.

\section{Metode Penelitian}

Jenis penelitian yang digunakan adalah penelitian kuantitatif, karena penelitian ini di sajikan dengan angka - angka. Hal ini sesuai dengan pendapat (arikunto 2006:12) yang mengemukakan penelitian kuantitatif adalah pendekatan penelitian yang banyak dituntut menggunakan angka - angka, mulai dari pengumpulan data, penafsiran terhadap data tersebut, serta penampilan hasilnya. Jenis penelitian ini merupakan penelitian cause and effect. Penelitian cause and effect adalah hubungan sebab akibat, bila X maka Y. Biasanya dilakukan untuk mengkaji kemungkinan hubungan sebab akibat antara faktor tertentu yang mungkin menjadi penyebab gejala yang diselidiki. Penelitian ini dilakukan oleh peneliti bertujuan untuk mengkaji pengaruh motivasi $X_{1}$ dan minat $X_{2}$ terhadap hasil belajar matematika (Y).

Populasi dalam penelitian ini adalah siswa di SMP Negeri 9 Padangsidimpuan di kelas VII.

Peneliti mengambil sampel dari 8 kelas dan 32 siswa yang ada di SMP Negeri 9 Padangsidimpuan. Teknik pengambilan sampel yang digunakan adalah dengan teknik Cluster Random Sampling.

Tabel 1 jumlah kelas dan siswa kelas VII SMP Negeri 9 Padangsidimpuan

\begin{tabular}{ccc}
\hline NO & Kelas & Banyak siswa \\
\hline 1 & VII - A & 26 \\
\hline 2 & VII - B & 27 \\
\hline 3 & VII -C & 25 \\
\hline 4 & VII - D & 25 \\
\hline 5 & VII - E & 25 \\
\hline 6 & VII - F & 25 \\
\hline 7 & VII - G & 25 \\
\hline 8 & VII - H & 26 \\
\hline & Jumlah & 204 \\
\hline
\end{tabular}

\section{Hasil Penelitian}

Peneliti mengambil sampel dari 8 kelas dari 204 siswa yang ada di SMP Negeri 9 Padangsidimpuan. Teknik pengambilan sampel dengan teknik Cluster Random Sampling. Untuk menentukan sampel mana yang akan dijadikan sumber data, maka pengambilan sampelnya berdasarkan kelas populasi yang telah ditetapkan. 
ISSN.2621-9832

JURNAL MathEdu (MathematicEducationJournal) http://journal.ipts.ac.id/index.php/MathEdu Vol. 4 . No. 3 November 2021

Langkah - langkah yang digunakan adalah sebagai berikut:

1.Susun sampling frame berdasarkan ruangan, dalam skripsi ini elemennya ada 204 siswa.

2.Tentukan dalam satu kelas diambil sampel.

3.Pilih siswa sebagai sampel dengan cara acak.

4.Teliti setiap siswa yang ada dalam kelas sampel.

Dalam penelitian ini sudah ditentukan jumlah kelas yang menjadi sampel dalam penelitian ini sebanyak 8 kelas dengan ketentuan sebagai berikut kelas VII-A sebanyak 5 siswa, kelas VII-B sebanyak 5 siswa, kelas VII-C sebanyak 4 siswa, kelas VII-D sebanyak 4 siswa, kelas VII-E sebanyak 4 siswa, kelas VIIF sebanyak 4 siswa, kelas VII-G sebanyak 3 siswa, kelas VII-H sebanyak 3 siswa. Hasil penelitian ini membahas tentang pengaruh motivasi dan minat terhadap hasil belajar matematika pada pokok bahasan persamaan linear satu variabel pada siswa kelas VII SMP Negeri 9 Padangsidimpuan.

Penelitian ini mengambil populasi yakni seluruh siswa kelas VII SMP Negeri 9 Padangsidimpuan. Sedangkan sampel pada penelitian ini sebanyak 8 kelas dengan ketentuan sebagai berikut: kelas VII-A sebanyak 5 siswa, kelas VII-B sebanyak 5 siswa, kelas VII-C sebanyak 4 siswa, kelas VII-D sebanyak 4 siswa, kelas VII-E sebanyak 4 siswa, kelas VII-F sebanyak 4 siswa, kelas VII-G sebanyak 3 siswa, dan kelas VII-H sebanyak 3 siswa, maka jumlah sampel adalah berjumlah 32 siswa. Penelitian ini termasuk penelitian kuantotatif karena penelitian ini bertujuan untuk mengetahui hubungan sebab akibat, bila X maka Y, dimana penelitian ini dilakukan oleh peneliti bertujuan untuk mengkaji pengaruh motivasi $\mathrm{X}_{1}$ dan minat $\mathrm{X}_{2}$ terhadap hasil belajar matematika (Y).

Dari hasil perhitungan pada motivasi dan minat dapat dilihat bahwa nilai koefisien determinasi menunjukkan besarnya pengaruh antara motivasi dan minat belajar siswa terhadap hasil belajar matematika. Untuk motivasi besarnya koefisien determinasi senilai dengan 39,13\% sedangkan untuk minat besarnya koefisien determinasi senilai dengan 19,1\%, ini jelas terlihat bahwa motivasi dan minat belajar lebih besar pengaruhnya terhadap hasil belajar matematika pada siswa kelas VII SMP Negeri 9 Padangsidimpuan.

\section{Kesimpulan}

Berdasarkan analisis data hasil penelitian dapat disimpulkan bahwa :

1. Dari hasil penelitian, ada pengaruh yang signifikan antara motivasi dan minat belajar pada mata pelajaran matematika kelas VII SMP Negeri 9 Padangsidimpuan.

2. Dari hasil perhitungan motivasi dan minat dapat dilihat bahwa nilai koefisien determinasi menunjukkan besarnya pengaruh antara motivasi dan minat belajar siswa terhadap hasil belajar matematika. Untuk motivasi besarnya koefisien determinasi sebesar $R^{2}=0,39,13 \%$ atau senilai dengan $\%$ sedangkan untuk minat besarnya koefisien determinasi $R^{2}=0,191$ atau senilai dengan 19,1\% ini jelas terlihat bahwa motivasi dan minat belajar lebih besar pengaruhnya terhadap hasil belajar matematika pada siswa kelas VII SMP Negeri 9 Padangsidimpuan.

\section{DAFTAR PUSTAKA}

Arikunto, Suharsimi 1996. Evaluasi Pendidikan. Jakarta: Rineka Cipta.

Arikunto, Suharsimi 2002. Dasar-dasar Evaluasi Pendidikan (Edisi Revisi). Jakarta: Bumi aksara. Arikunto, Suharsimi 2002. Prosedur Penelitian Suatu Pendekatan Praktek. Jakarta: Rineka Cipta.

Chatarina, Anni 2004. Psikologi Belajar. Semarang: UNNES PRES

Dimyanti, Mudjiyono 2022. Belajar dan Pembelajaran. Jakarta: DEPDIKBUD

Djali 2006. Psikologi Pendidikan. Jakarta: PT Bumi aksara.

Hadi, Sutrisno 1995. Analisis Regresi. Yogyakarta: Andi Offset.

Hamalik, Oemar 2001. Proses Belajar Mengajar. Jakarta: PT Bumi aksara.

Iskandar, Yul 2005. Test Bakat, Minat, Sikap dan Personaliti MMPI-DG. Jakarta: Dharma Graha Group. 